\title{
UPAYA PELESTARIAN RUMAH ADAT KARO MELALUI RUPA RAGAM HIAS DI SUMATRA UTARA
}

\author{
Seriwati Ginting, Heddy Heryadi, Sri Bina Carolina \\ (seriwati.ginting@maranatha.edu, heddy.heriyadi@art.maranatha.edu \\ Desain Komunikasi Visual \\ Fakultas Seni Rupa dan Desain \\ Universitas Kristen Maranatha \\ Jalan Surya Sumantri no 65 Bandung
}

\begin{abstract}
ABSTRAK
Keberadaan rumah adat Karo semakin langka padahal memiliki nilai budaya yang tinggi. Bentuk bangunan yang megah menjulang serta ragam hias di sepanjang dindingnya.

Rumah adat Karo disebut Siwalauh Jabu (delapan keluarga tinggal di dalamnya). Proses pembuatan dan kehidupan penghuninya diatur sedemikian rupa di dalam adat.Ragam hias di rumah Karo disebut "Ukir-ukiren" atau Gerga.Ragam hias dibuat dan ditempatkan di bangunan rumah dengan makna dan nilai nilai kepercayaan yang diyakini secara turun temurun. Aplikasi warnanya terdiri dari warna merah, hijau, hitam dan kuning. Teridentifikasinya rumah adat dan pola ragam hias Karo yang sudah di ambang kerusakan bahkan punah. Metode yang digunakan dalam penelitian ini adalah metode deskriptif kualitatif melalui observasi, wawancara, studi literatur dan dokumentasi. Teknik yang digunakan untuk menganalisis adalah pengumpulan data, reduksi data display dan menarik kesimpulan. Penelitian ini bertujuan menggambarkan kondisi keberadaan rumah adat Karo dan ragam hias sebagai satu kesatuan. Gambaran keberadaan ini diharapkan menggugah masyarakat, dinas terkait dan pemerintah untuk melestarikannya sebagai suatu kebanggaan dan kekayaan bangsa.
\end{abstract}

Kata kunci : ;budaya ,ragam hias ,pola ,rumah karo ;tradisi

\begin{abstract}
The existence of Karo traditional houses is increasingly rare even though it has high cultural value. The form of the building is magnificent and towers along the walls. Karo's traditional house is called Siwalauh Jabu (eight families live in it). The process of making and the life of its inhabitants is arranged in such a way. The value of trust values that are believed from generation to generation. The color application consists of red, green, black and yellow. Identification of traditional houses and Karo decorative patterns that are on the verge of damage and even extinction. The method used in this research is a qualitative descriptive method through observation, interviews, literature study and documentation. The techniques used to analyze are data collection, display data reduction and drawing conclusions. This study aims to describe the conditions of the existence of the Karo traditional house and its
\end{abstract}


decorative styles as one unit. This image of existence is expected to inspire the public, related agencies and the government to preserve it as a national pride and wealth.

Keywords: culture ; decoration ; pattern ; karo house ; tradition

\section{PENDAHULUAN}

Rumah adat Karo atau Siwaluh Jabu memiliki bentuk yang unik. Rumah adat ini merupakan warisan dari leluhur. Dinding rumahnya tidak berdiri tegak lurus, melainkan dengan sudut kemiringan 120 derajat, panjangnya sekitar 12 meter dan tingginya 12 meter (Kebudayaan.kemendikbud.go.id). Rumah adat karo berbentuk rumah Panggung yang tingginya 2 meter dari permukaan tanah (Sinulingga, 2016). Keberadaan rumah adat ini dipengaruhi oleh sosialkultur masyarakatnya, keadaan alam lingkungan, adat istiadat, religi dan sistem kekerabatan. Suku Karo merupakan salah satu suku yang terdapat di Sumatra Utara. Mereka menamakan tempat tinggalnya sebagai Tanah Karo Simalem (tempat yang tenang, damai dan nyaman). Diyakini sebagai penetapan dari Tuhan yang diperuntukkan untuk lima merga yang terdiri dari Ginting, Karo-Karo, Sembiring, Tarigan dan Perangin angin. Merga bagi orang Karo adalah identitas yang paling utama dan sekaligus penentuan system kekerabatan (Tarigan, 2018 : 98).

Sebelumnya masyarakat Karo memeluk kepercayaan kiniteken Sipemena (kepercayaan asli) secara turun temurun, tetapi dalam perkembangannya masyarakat Karo memeluk agama Hindu, Budha, Kristen dan Islam. Perbedaan agama bukanlah hal yang membuat keluarga menjadi terpisah. Suku Karo tidak membedakan antara kategori kategori seperti "religion" (agama), "magic" (kekuatan sihir), "custom" (adat istiadat), "culture" (budaya), "belief" (kepercayaan) dan ceremony (perayaan) yang dinyatakan sebagai satu bentuk (sepaket) dengan perbegu. Istilah perbegu sangat erat kaitannya dengan keberadaan begu/roh roh leluhur (Ginting, 2013). Suku Karo memiliki ciri yang membedakannya dengan suku 
Serat Rupa Journal of Design, January 2021, Vol.5, No.1: 122-141

E-ISSN: 2477-586X, ISSN: 2338-3348 | https://doi.org/10.28932/srjd.v5i1.2868 |

Received: 30- 10- 2019, Accepted: 16- 01- 2021

Seriwati Ginting, Heddy Heriyadi, Sri Bina Carolina

Upaya Pelestarian Rumah Adat Karo Melalui Rupa Ragam Hias di Sumatra Utara

lain, yaitu, merga, bahasa, kesenian dan adat istiadat, (Tarigan, 2018:23). Pakaian adat merupakan pakaian yang digunakan pada saat upaca adat seperti pernikahan, peresmian rumah baru, kematian dan lain lain.

Pakaian adat Karo didominasi warna merah (Sitepu dan Ardoni, 2019). Rumah adat Karo menggambarkan komunitas sosial, solidaritas dan ritual. Rumah adat ini memiliki ragam hias di sepanjang bagian dinding (derpih). Ragam hias juga merupakan symbol symbol atau falsafah hidup orang Karo (Maundyni, dkk 2019) Rumah adat Siwaluh Jabu (siwaluh artinya delapan, jabu artinya rumah) dihuni delapan keluarga, sehingga terlihat adanya hubungan ketiga elemen yakni kalimbubu, anak beru dan senina (Ginting, 2013). Yang dimaksud kalimbubu adalah pihak keluarga (pemberi) istri, yakni orang tua dan saudara saudara dari pihak perempuan/istri. Anak beru berarti pihak penerima istri (orang tua dan saudara saudara dari pihak laki laki/suami). Senina adalah mereka yang bersaudara karena mempunyai merga (nama keluarga) yang sama (http://kamus.karo.or.id). Rumah adat Karo merupakan rumah panggung yang bangunannya tidak menggunakan paku. Disebut rumah adat karena pondasi utama masyarakat Karo adalah adat istiadat. Seluruh proses pembangunan dilakukan dengan bantuan orang pintar (guru/dukun). Mulai dari menentukan lokasi, pemilihan bahan bangunan, menentukan hari baik, peresmian dan juga posisi keluarga di dalam rumah adat.

Bagian dalam rumah dibagi menjadi delapan ruangan tanpa adanya sekat, kecuali kamar. Setiap keluarga menempati satu ruangan yang terdiri atas dua kamar tidur, satu dapur dan satu ruang keluarga. Satu dapur digunakan oleh dua keluarga. Dapur dibuat berhadap hadapan agar dapat digunakan oleh dua keluarga. Ruang keluarga (ruang tengah) berfungsi sebagai ruang tamu. Rumah adat Karo sangat kaya dengan nilai nilai. Nilai nilai tersebut tergambar dalam ragam hias yang dimiliki oleh masyarakat Karo. Penempatan ragam hias terdapat pada derpih (dinding), pada sudut bangunan (suki-suki), pada bagian depan atas (posisinya dekat dengan kepala kerbau), kepala kerbau merupakan puncak bangunan dari 
rumah adat Karo. Kepala kerbau diyakini sebagai penjaga atau pelindung. Bagi masyarakat Karo kepala kerbau memiliki nilai sacral (Maundyni dkk, 2019). Nama ragam hias yang terdapat pada dinding antara lain; Desa Siwaluh, Tapak Raja Sulaiman, Bindu Matagah dan lain lain. Setiap ragam hias ini memiliki bentuk, warna dan makna yang berbeda.

Berdasarkan sejarahnya, ragam hias yang dimiliki oleh masyarakat Karo dimaksudkan sebagai penolak bala, menangkal roh jahat dan untuk maksud pengobatan (Tarigan, $2018: 276)$.

Berikut ini nama dan makna dari ragam hias Rumah Adat Karo (dari berbagai sumber)

1. Desa Siwaluh digunakan sebagai penunjuk mata angin dan untuk menentukan arah yang baik dan yang buruk.

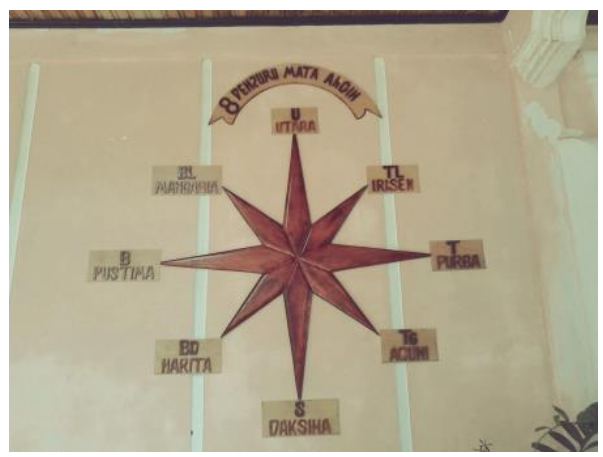

Gambar 1. Desa Siwaluh

(https://museumgbkpsukamakmur.files.wordpress.com/2013/07/desasiwaluh.jpg)

2. Tapak Raja Sulaiman yang berfungsi untuk penunjuk jalan supaya tidak tersesat, khususnya pada saat seseorang masuk hutan 


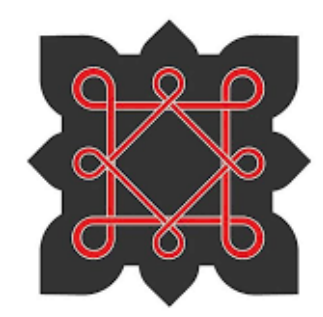

Gambar. 2 Tapak Raja Sulaiman

Sumber: repository.usu.ac.id

3. Bindu Matagah dimaksudkan agar terhindar dari gangguan binatang buas saat masuk hutan

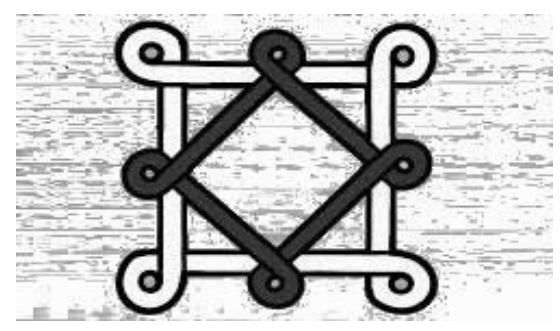

Gambar 3.Bindu Matagah

(Sumber; Tarigan 2018)

4. Pengeret ngeret melambangkan kekuatan, kewaspadaan dan kesatuan keluarga.

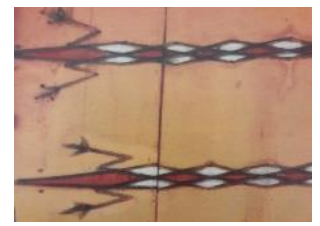

Gambar 4 Pengeret ngeret

Sumber; Data lapangan Sri Bina

5. Taruk Taruk melambangkan kesuburan, kemakmuran dan keluarga. 


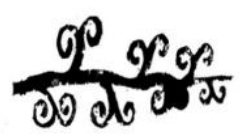

Gambar 5. Taruk-taruk Sumber; Tarigan, 2018

Ragam Hias yang dari tanaman Pada rumah adat Karo ada pula yang diisnpirasi dari flora dan fauna. Berikut ini ragam hias yang terinspirasi dari tumbuhan dan Hewan.

\section{Embun Sikawiten dan Tulak Paku sebagai hiasan}

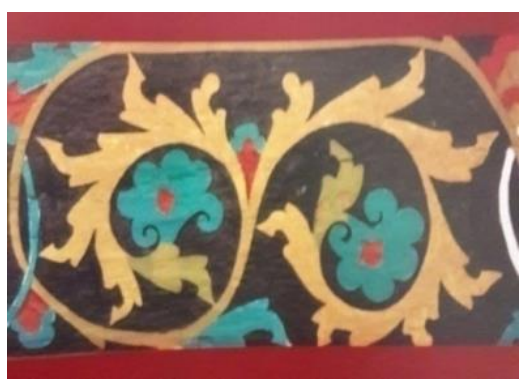

Gambar 6. Embun Sikawiten Sumber: Data lapangan Sri Bina

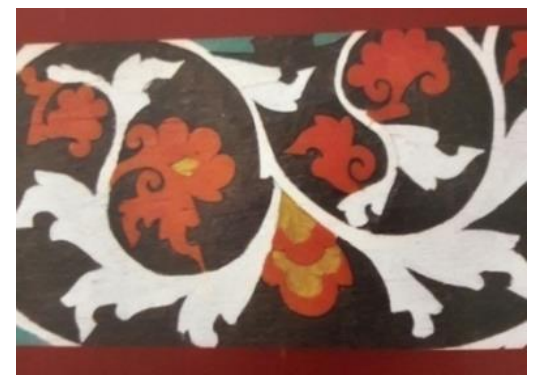

Gambar 7. Tulak Paku

Sumber: Data lapangan Sri Bina

\section{Pengereteret}




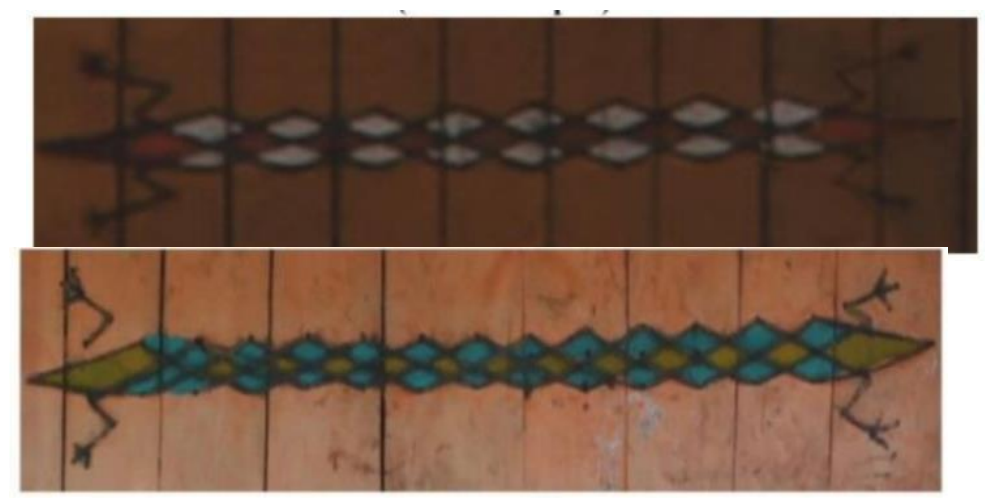

Gambar.8 Pengereteret dengan warna berbeda Sumber : Fauzi Jufli 2012

Ragam hias yang dimiliki olah masyarakat Karo beragam jenis, motif dan juga makna. Ada kalanya satu ragam hias tetapi mengandung banyak makna. Misalnya ragam hias Tapak Raja Sulaiman (pada gambar 2) memiliki makna sebagai penolak bala, menahan roh roh jahat, anti racun, dan penunjuk jalan apabila tersesat di perjalanan terutama di hutan. Penerapan ragam hias pada dinding (derpih) tidak selalu berdiri sendiri. Beberapa ragam hias dipadukan menjadi satu. Warna ragam hias terdiri atas merah, hitam dan kuning. Selain ditempatkan pada rumah adat, ragam hias juga diimplementasikan pada berbagai perlengkapan yang digunakan sehari hari. Misalnya pada ukat (sendok sayur), gantang (sejenis alat takar beras), cincin, kalung anak anak, cimba lau (gayung) serta pada pakaian adat seperti; uis gara, tudung, bulang bulang dan sebagainya (Tarigan $2018: 276$ ).

Rumah adat Karo pada zaman dahulu telah membuktikan bahwa keterbatasan wawasan pengetahuan tidak menghalangi mereka untuk berkarya dan menghasilkan sesuatu yang berguna bagi anak dan cucu (Saraswaty dan Suprayitno, 2017). Sayangnya kondisi rumah adat Karo saat ini memprihantikan, bahkan di ambang kerusakan karena kurang pemeliharaan. (Daulat Saragi, 2018). Saat ini sulit menjumpai keberadaan rumah adat Karo. Bahkan beberapa desa sudah punah rumah adatnya. Hanya beberapa desa yang masih memiliki rumah adat Karo, dengan jumlah terbatas dan kondisi yang kurang terawat. Pada tahun 
2011 masih ada 18 rumah adat tradisional Karo yang tersebar di beberapa desa, seperti desa Dokan, Lingga, Pececer, Kabung, Paribun dan desa Tanjung Barus (Erdansyah, 2011). Berdasarkan verifikasi tanggal 26 Oktober 2013 jumlah rumah adat Karo hanya ada 8 unit dengan rincian sebagai berikut Desa Lingga ada 2 Unit, desa Dokan 5 unit dan desa Pececer ada 1 unit (https://kebudayaan.kemendikbud.go.id/ditwdb/rumah-adat-karo/). Pentingya penelitian ini untuk menumbuhkan kesadaran yang mendalam, rasa memiliki dan perhatian dari berbagai pihak untuk ikut menjaga dan memelihara rumah adat Karo yang masih tersisa agar kelestariannya terjaga secara utuh (bangunan rumah, ragam hias dan ruang bagian dalam rumah). Hasil observasi menunjukkan bahwa ruang bagian dalam kurang terawat). Peremajaan dilakukan hanya satu kali dalam setahun, dengan melakukan pengecetan, dan peralatan yang digunakanpun peralatan seadanya dan biaya yang minim (Agustriana, 2016)

Hipotesis

Kurangnya perhatian dan kesadaran dari masyarakat Karo, pemuka adat Karo, dan pemerintah daerah terhadap keberadaan rumah adat Karo, menyebabkan rumah adat Karo beserta ragam hiasnya hampir punah. Saat ini hampir semua desa sudah tidak "menyimpan" rumah adat Karo. Bila hal ini terus dibiarkan maka keberadaan rumah adat tradisional Karo sebagai salah satu kekayaan kebudayaan akan punah dan generasi bangsa ini tidak akan pernah mengenal dan mengetahui bahwa rumah tradisional adat Karo menyimpan kekayaan budaya yang luar biasa.

\section{METODE PENELITIAN}

Metode penelitian yang digunakan adalah metode kualitatif deskriptif. Objek penelitiannya adalah rumah adat tradisional Karo berikut ragam hias yang terdapat pada bangunan rumah adat Karo di desa Lingga di kecamatan Simpang Empat Kabupaten karo. Ragam hias bagi masyarakat Karo merupakan simbol yang memiliki nilai sakral, dipercaya dapat menjaga dan melindungi penghuni rumah adat. Pengumpulan data dilakukan dengan observasi ke desa Lingga, membuat 
catatan lapangan, memotret rumah adat dari beberapa sudut, memotret setiap ragam hias pada dinding, pada bagian atas rumah (ayo) dan bagian dalam rumah adat, kemudian didokumentasikan. Data yang terkumpul dipilah dan dikelompokkan sesuai dengan tujuan penelitian. Subyek penelitian adalah penghuni rumah adat tradisional Karo di desa Lingga, pemuka adat serta Dinas pariwisata. Wawancara dilakukan dengan penghuni rumah, pemuka adat berikut pemerintah daerah setempat. Selanjutnya dilakukan kajian dokumen melalui berbagai sumber. Reduksi data dilaksanakan dengan memilih data data yang terkait dengan penelitian. Objek dinarasikan terlebih dahulu (rumah adat dan ragam hiasnya) beserta nilai dan makna yang ada di dalamnya untuk kemudian diintepretasikan. Selain itu dilakukan pula studi literature untuk mendukung hasil penelitian. Buku buku yang ditulis oleh penulis Karo atau yang tinggal menetap di tanah Karo, menjadi prioritas, karena kami yakini tidak hanya mengetahui tetapi juga sangat memahami tentang rumah adat Karo. Melengkapi data dan informasi untuk tulisan ini, maka dilakukan juga kajian dari berbagai jurnal yang relevan dengan maksud dan tujuan dari penelitian ini.

\section{PEMBAHASAN}

Rumah adat Karo yang disebut Siwaluh Jabu, didiami delapan keluarga dan setiap keluarga mempunyai peranan dan fungsi. Ada yang menjadi kepala rumah, ada yang menjadi sekretaris dan menjadi anggota. Rumah adat dibangun dengan mengikuti petunjuk dari guru (orang pintar, dukun). Dimulai dengan menentukan lokasi sebab dalam kepercayaan orang Karo ada tanah yang baik untuk didiami dan ada juga yang tidak baik. Tanah yang baik itu mendatangkan kesehatan, ketentaraman bagi semua penghuni rumah sebaliknya tanah yang tidak baik dapat mendatangkan mala petaka dan sakit penyakit kepada penghuni rumah. Selanjutnya menyiapkan dan memilih bahan bangunan yang semuanya diambil dari hutan. Setelah semua bahan bangunan dipandang cukup maka ditentukan hari baik untuk memulai pembangunan rumah adat. Proses pembangunan dilaksanakan secara gotong royong, mulai dari menarik kayu, memotong kayu dan 
membangun. Waktu yang digubakan untuk membangun rumah adat Karo kurang lebih dua tahun karena memang pengerjaan yang rumit. Pembangunan rumah adat selalu diiringi dengan penempatan ragam hias pada bangunannya. Setiap ragam hias (gerga/ukir-ukiren) mempunyai simbol dan makna bagi masyarakat Karo. Dalam perkembangannya dari waktu ke waktu kebiasaan membuat ukiran tersebut sudah tidak ada karena rumah adat Karo juga terus berkurang jumlahnya. Keberadaan ragam hias saat ini oleh sebagian masyarakat Karo dipandang sebagai suatu keindahan. Generasi muda Karo yang lahir di perantauan sudah tidak mengenal ragam hias. Mereka juga tidak dapat menyebutkan Nama ragam hias, simbol maupun makna yang terkandung dalam ragam hias. Kegiatan membersihkan rumah adat Karo biasanya dilakukan satu kali dalam setahun yaitu menjelang Merdang merdem atau pesta tahunan (sebagai ungkapan syukur atau sukacita atas panen yang telah berhasil dan menyiapkan diri menyambut musim tanam yang berikutnya).

Rumah adat Karo menggambarkan komunitas sosial, solidaritas dan ritual. Rumah adat Karo dihuni oleh delapan keluarga dari berbagai hubungan yang mencakup tiga elemen seperti kalimbubu, anak beru dan seninan. Yang dimaksud kalimbubu adalah pihak yang memberikan (pemberi) istri. Pihak keluarga suami selalu hormat kepada pihak keluarga isteri dan menganggap kedudukannya tetap lebih tinggi, hal ini nampak dalam pembagian jabu, yang paling dihormati selalu menempati jabu bena kaju. Kalimbubu itu adalah tempat meminta dan tempat bertanya, selalu diperlukan restunya dalam adat dan penghormatan dalam musyawarah adat. Anak beru berarti pihak penerima istri dan yang mengetahui keadaan senina dan kalimbubu.

Berikut ini pembagian ruang dalam pada rumah adat Karo:

1. Jabu benakayu adalah rumah tangga pangkal kayu. Jabu ini juga disebut Jabu Raja. Pada jabu ini tinggal keluarga raja keluarga pemilik tanah, penghuni utama rumah adat. 
Serat Rupa Journal of Design, January 2021, Vol.5, No.1: 122-141

E-ISSN: 2477-586X, ISSN: 2338-3348 | https://doi.org/10.28932/srjd.v5i1.2868 |

Received: 30- 10- 2019, Accepted: 16- 01- 2021

Seriwati Ginting, Heddy Heriyadi, Sri Bina Carolina

Upaya Pelestarian Rumah Adat Karo Melalui Rupa Ragam Hias di Sumatra Utara

2. Jabu Ujungkayu adalah rumah tangga ujung kayu. Jabu ini didiami oleh anak beru dari jabu benakayu

3. Jabu Lepar Benakayu berarti jabu seberang benakaayu. Biasanya penghuni jabu ini adalah anak penghuni utama rumah adat.

4. Jabu Lepar Ujung Kayu berarti jabu yang terletak di seberang jabu ujungkayu. Yang mendiami jabu ini biasanya kalimbu dari penghuni jabu benakayu

5. Jabi Sidapurkeun benkayu berarti jabu yang sedapur dengan jabu bena kayu. Yang menempati jabu pada umumnya anak beru

6. Jabu sidapurken ujungkayu berarti jabu yang sedapu dengan jabu ujungkayu. Penghuni jabu ini adalah anak kalimbubu

7. Jabu sidapurken lepar ujungkayu adalah jabu yang sedapur dengan jabu seberang kayu. Jabu ini biasa juga disebut jabu bicara guru. Dinamai begitu karena jabu ini biasa ditempati oleh orang orang yang termasuk golongan guru atau dukun

8. Jabu didapurkeun lepar benakayu adalah jabu yang sedapur dengan jabu seberang benakayu. Jabu ini disebut juga jabu si ngapuri belo berarti jabu orang yang menyediakan sekapur sirih (Saraswaty dan Suprayitno, 2017).

Susunan keluarga dalam rumah adat siwaluh jabu itu mempunyai tugas kewajiban masing masing. Walaupun tugas tugas tersebut telah terbagi bagi, namun semuanya merupakan suatu keutuhan yang tidak dapat dipisahkan. Rumah si waluh jabu mempunyai dua ture atau teras/beranda. Ture memiliki panjang kira kira $4 \mathrm{~m}$ lebar sekitar $2 \mathrm{~m}$ dan tingginya 1,5 meter dari tanah. Ture terbuat dari potongan bambu besar atau buluh mbelin. Selain sebagai beranda rumah ture juga mempunyai beberapa fungsi lain seperti, tempat menyimpan atau meletakkan kayu bakar, tempat menjemur padi atau jagung, tempat menampi beras sebelum ditanak. Selain itu ture juga sering digunakan sebagai tempat menganyam tikar dan sumpit nakan (wadah yang digunakan untuk menyimpan 
beras atau menyimpan nasi). Menganyam dilakukan para gadis sambil menunggu pujaan hatinya datang berkunjung.

Desa Lingga merupakan salah satu kampung adat Karo. Disebut kampung adat karena di desa Lingga masih ditemukan rumah adat Karo dan masih dihuni oleh empat keluarga sehingga ada ruangan ruangan yang dibiarkan kosong. Rumah adat ini sudah dijadikan sebagai tujuan wisata namun saat observasi, kondisi di dalam rumah adat tampak tidak terawat. Dari informasi yang diperoleh banunan tersebut diperkirakan sudah berusia sekitar seratus limapuluh tahun dan tidak dirawat secara intensif. Semakin berkurangnya rumah adat tradisional Karo menyebabkan para "pandai/ahli" ragam hias Karo semakin sulit ditemui. Keberadaan rumah adat seharusnya menjadi bagian dari suatu budaya. Budaya yang dijaga, dilindungi dan dilestarikan sebagai warisan bagi anak cucu dan kebanggaan bagi dunia international. Karena keberadaan rumah adat menjadi suatu bukti bagi kita semua bahwa keterbatasan pengetahuan bukan menjadi alasan dalam berkarya. Melalui keberadaan rumah adat Karo ini kita dapat menunjukkan betapa kayanya keberagaman dan nilai nilai yang dimiliki bangsa Indonesia. Kebanggan itu juga semakin lengkap karena masyarakat Karo sudah bisa membuat bangunan yang tahan gempa, pembangunanya tidak menggunakan paku, kawat dan baja. Sistem kekeluargaan yang sangat erat karena delapan keluarga tinggal dalam satu rumah. Namun sayangnya keberadaan rumah adat "kurang mendapat perhatian" baik dari masyarakat Karo maupun dari pemerintah daerah. Modernitas dan kepratisan membuat masyarakat karo enggan tinggal di rumah adat. Rumah adat yang dibiarkan kosong akhirnya ambruk. Diakui ada beberapa upaya yang telah dilakukan oleh masyarakat bersama dengan pemerintah namun upaya tersebut masih bersifat tambal sulam. Budaya suatu bangsa adalah gambaran cara hidup dari bangsa yang bersangkutan. Tinggi rendahnya budaya suatu bangsa, tercermin dari materi materi budaya yang ada pada bangsa tersebut, (Tarigan, 2018). Diungkapkan bahwa masyarakat Karo pada 
masa lampau telah memiliki budaya yang cukup tinggi karena memiliki hal hal berikut ini :

a. Tatanan kehidupan masyarakat karo yang terikat di dalam suatu sistem, yaitu Merga Silima, Tutur Siwaluh, Rakut Sitelu.

b. Tulisan dan Bahasa Karo yang cukup kaya (perhatikan istilah bisbis, cekurang, meluat (kotor/jorok), permalna, mbergohna, daluna (betina, biasanya digunakan untuk hewan), buganna Jantan biasa digunakan untuk hewan), bajarna, iluh (air mata), dan masih banyak lagi)

c. Peralatan hidup yang cukup lengkap seperti : kudin (sejenis dandang untuk menanak nasi), tendang (lampu), ukat (sendok nasi), kerpe, busan busan, cuan, kiskis (menggaruk bagian tubuh yang terasa gatal), capah (piring besar), sapo (gubuk, biasanya terdapat di sawah atau kembun sebagai tempat istirahat atau tempat berteduh kala hujan atau terik matahari), sangketen (tempat untuk menggantungkan benda benda seperti baju), kampoh (kain sarung), sekin (pisau besar/parang), tajak (linggis), banangun, palas, ret-ret sangka, mamok dan sebagainya. Dijelaskan lebih lanjut bahwa semua penyebutan di atas memiliki nilai yang tinggi sebab semua berasal dari bahasa Karo "asli" dan bukan berasal dari bahasa asing

d. Pembinaan kepercayaan serta tata cara pelaksanaannya seperti ngalang tendi, perumah begu, persilihi, erpangir ku lau dan sebagainya.

e. Alat alat kesenian Karo yang beragam jenisnya, sesuai dengan kepentingannya, seperti perangkat gendang, sarune, gendang gunung, pengarak, belobat, sordam, kulcapi, keteng-keteng dan sebagainya

f. Ragam busana baik bagi pria maupun bagi wanita. Bentuk busananya berbeda beda dalam berbagai jenis dan ragam pesta. Seperti pesta perkawinan, guro guro aron, kemalangan, ngelandekken galuh dan sebagainya

g. Penentuan hari untuk turun ke ladang menanam padi, didasarkan pada musim (semacam ramalan cuaca)

h. Nama nama hari seperti aditia, suma, nggara dan sebagainya. 
Masyarakat Karo sangat unik dan memiliki budaya yang sangat kuat. Namun dari yang dipaparkan tersebut, tidak secara spesifik mengungkapkan rumah adat sebagai bagian dari Budaya, walaupun dalam buku tersebut dicantumkan dan lain lain. Identitas yang secara "ketat" dipegang oleh masyarakat Karo adalah merga, Bahasa, kesenian dan adat istiadat. Penetapan identitas ini tidak menyebutkan rumah adat Karo sebagai identitas. Bisa jadi karena tidak dikategorikan sebagai identitas pada masyarakat Karo maka kesadaran dalam menjaga dan memelihara menjadi tidak kuat. Hal ini juga yang menarik bagi peneliti mengingat nilai pada rumah adat Karo sarat makna yang dapat dikaji dari simbol dan penempatannya pada bagian rumah adat Karo.

Rumah adat suku Karo dibangun dengan material alam, (kayu, bambu, ijuk). Struktur bangunannya dibuat dengan bentuk persegi panjang, pada bagian dalam tidak banyak ruangan. Pembagian ruangan di dalam rumah adat Karo hanya difungsikan sebagai ruang tidur.

Pada bagian luar ditempatkan berbagai ragam hias yang pembuatannya ada yang diukir dan ada pula anyaman dari jalinan bambu. Pada bagian depan rumah/ayo (posisinya dekat atap) ditempatkan ragam hias berupa anyaman bambu, sedangkan pada dinding dibuat dengan ragam hias dengan teknik ukiran dan diberi warna. Ragam hias pada rumah adat Karo terinspirasi dari alam, hewan, dan tanaman. Selain itu pada rumah adat Karo juga terdapat ragam hias bentuk geometris, seperti segitiga dan persegi. Ragam hias Karo tidak hanya diaplikasikan pada rumah adat, tetapi juga pada berbagai benda pakai dan peralatan makan. Fungsi ragam hias yang terdapat pada bangunan rumah adat Karo, sebagai identitas, strata golongan sosial, juga sebagai penolak bala (Saragi, 2018).

Rumah adat Karo sangat unik karena selain bentuknya yang tampak megah (menjulang tinggi), tahan gempa, desain arsitekturnya mengaggumkan, terbuat dari kayu tanpa paku (hanya menggunakan tali) sebagai pengikatnya. Ornamen 
Serat Rupa Journal of Design, January 2021, Vol.5, No.1: 122-141

E-ISSN: 2477-586X, ISSN: 2338-3348 | https://doi.org/10.28932/srjd.v5i1.2868 |

Received: 30- 10- 2019, Accepted: 16- 01- 2021

Seriwati Ginting, Heddy Heriyadi, Sri Bina Carolina

Upaya Pelestarian Rumah Adat Karo Melalui Rupa Ragam Hias di Sumatra Utara

atau biasa juga disebut ragam hias terdiri dari berbagai jenis motif sehingga semakin indahlah tampilan dari rumah adat Karo. Di bagian atap paling atas dari rumah adat pasti diletakkan kepala kerbau lengkap dengan tanduk tanduknya. Kepala kerbau sebagai lambang kekuatan dan penangkal mara bahaya, diyakini orang yang mmeiliki niat jahat tidak bisa masuk ke dalam rumah. Dahulu saat penghuni berangkat ke sawah atau kebun pintu hanya ditutup dan tidak dikunci. Mereka meyakini ada yang "menjaga" rumahnya. Terkait budaya memiliki cakupan sangat luas. Salah satunya adalah rumah adat Karo yang dengan keunikkan dalam bentuk bangunan, ragam hias, proses pembangunan, maupun ruang yang ada di dalamnya. Keberadaan rumah adat Karo yang megah tersebut semakin langka dan hampir punah. Perlu diteliti, dituliskan dan didokumentasikan terkait dengan berbagai simbol dan makna yang tertuang di dalamnnya. Sangat disayangkan apabila tidak dijaga/dipelihara maka para generasi muda kehilangan informasi dan bahkan tidak mengenal/tidak tahu kekayaan budaya yang dimiliki oleh leluhurnya. Selanjutnya apakah kita rela dan kemudian menyesal di kemudian hari. Sebelum semuanya terlambat biarlah rumah adat yang masih "tersisa" dirawat, dijaga, dipelihara dan dilestarikan sebagai kebanggaan bersama anak bangsa.

Ada anggapan bahwa rumah adat Masyarakat Karo memiliki nilai mistis sebab hanya ditopang di atas batu batu besar yang tidak ditanam, bangunan yang ditopang cukup besar dan cukup berat. Keunikan ini menjadi daya tarik bagi wisatawan untuk berkunjung dan mencari tahu keunikan yang dimiliki. Sebagian besar motif ragam hias diangkat dari lingkungan sekitar. Berikut ini makna ragam hias yang terdapat pada rumah adat karo, antara lain:

1. Bindu Matagah di lambangkan sebagai anti bala atau menyingkirkan hal hal yang tidak baik. Bindu Matagah ini selain terdapat pada rumah adat, juga digambarkan di tanah. Diyakini apabila seseorang sudah menginjakkan kaki pada gambar Bindu Matagah maka orang tersebut terhindar dari gangguan binatang buas. Berdasarkan keyakinan tersebut maka orang yang berangkat ke hutan atau ke suatu tempat yang yang jauh 
terlebih dahulu menginjakkan kaki kanan pada gambar Bindu matagah agar terhindar dari berbagai gangguan binatang buas

2. Pantil Manggus (Pentil Manggis) berfungsi sebagai hiasan. Secara turun temurun sering diceritakan bahwa buah manggis memiliki khasiat yang sangat baik terhadap kesehatan dan saat ini hal tersebut ternyata sudah dibuktikan oleh para pakar. Tampilan buah manggis yang tampak luarnya tidak menarik ternyata menyimpan buah yang lezat, enak, lembut dan sekaligus bergizi. Pandangan ini diibaratkan agar dalam menilai seseorang, jangan hanya melihat dari tampilan luarnya saja. Sebab adakalanya tampilan luar yang sederhana dan mungkin kurang menarik, ternyata memiliki ilmu yang tinggi/wawasan, kepekaan dan kepedulian terhadap sesama dan lingkungan dan bisa juga sebaliknya orang yang tampilan luarnya rapi, terpelajar tapi ternyata tidak memiliki hati yang baik dan kepedulian terhadap sesama dan lingkungan.

3. Tulpak Salah Silimalima melambangkan kekeluargaan masyarakat Karo yang utuh dan dihormati. Motifnya berupa garis menyilang yang membentuk gambar bintang di langit. Fungsinya sebagai penolak bala/kejahatan terhadap merga silima sebagai suatu kebersamaan. Karena masyarakat Karo memandang kebersamaan sebagai suatu kekuatan. Kebersamaan orang Karo sangat kental terlihat dalam berbagai upaca adat. Seperti adat pernikahan apabila belum ada pihak senina, anak beru, dan kalimbubu maka proses adat belum bisa dilaksanakan. Satu pesan yang selalu disampaikan para orang tua kepada anak-anaknya agar teguh memegang adat. Pernikahan antara orang Karo dengan suku lain baru diakui apabila telah dilakukan acara adat. Yaitu pemberian merga bagi laki laki yang menikah dengan perempuan Karo dan pemberian Beru bagi perempuan yang menikah dengan laki laki dari suku Karo.

4. Lipan nangkih tongkeh, menggambarkan hewan lipan yang sedang memanjat/merayap. Berfungsi sebagai salah satu ragam hias tetapi juga menggambarkan kehidupan yang dinamis. Kehidupan yang mengalami 
Serat Rupa Journal of Design, January 2021, Vol.5, No.1: 122-141

E-ISSN: 2477-586X, ISSN: 2338-3348 | https://doi.org/10.28932/srjd.v5i1.2868 |

Received: 30- 10- 2019, Accepted: 16- 01- 2021

Seriwati Ginting, Heddy Heriyadi, Sri Bina Carolina

Upaya Pelestarian Rumah Adat Karo Melalui Rupa Ragam Hias di Sumatra Utara

banyak dinamika, lika liku. Penekannya kehidupan terus berubah. Perubahan yang diharapkan menuju kepada kebaikan dan kemuliaan. Bertambah wawasan/pengetahuan, bertambah kesabaran, bertambah dewasa, semakin bijaksana, semakin luas pergaulan dan semakin baik perekonomian/semakin sejahtera

5. Cekili kambing berbentuk seperti pintu yang cekung (garis garis lengkung yang berulang) Menggambarkan adanya tahap atau fase fase dalam kehidupan. Setiap fase memiliki tantangan dan setiap fase harus dilalui dengan penuh semangat. Selain itu setiap manusia memiliki keterbatasan di dalam dirinya. Menyadari keterbatasan ini menodorong orang untuk tidak sombong dan bisa menghargai keberadaan orang lain termasuk bisa menerima kekurangan orang lain

6. Ipen ipen. Ipen artinya gigi. Makna yang terkandung dalam ipen ipen ini adalah kesehatan gigi. Harapannya agar gigi anak anak sehat dan tidak terganggu/sakit gigi. Peran gigi bagi masyarakat Karo dipandang sangat berpengaruh pada kesehatan secara keseluruhan. Untuk memelihara agar gigi kuat dipercaya juga dengan "nyirih" (memakan daun sirih). Sirih yang dilengkapi dengan kapur sirih dan gambir diyakini dapat memperkuat gigi. Ragam hias Ipen ipen selain diterapkan pada rumah adat Karo juga diterapkan pada benda pakai sehari hari seperti pada peralatan makan, tempat menyimpan garam maupun pada tempat makanan anak.

7. Lukisan Suki. Suki diartikan sebagai bagian pojok/sudut dari suatu tempat/rumah. Jadi yang dimaksud lukisen suki adalah lukisan pada bagian kiri dan kanan rumah (melmelen). Suki juga dimaknai dalam kehidupan tidak perlu selalu harus "pamer" .Tidak perlu segala perbuatan baik harus diketahui oleh orang lain. Orang Karo memiliki sifat pekerja keras, mudah beradaptasi, dan tidak suka pamer. Kelebihan yang dimiliki tidak untuk dipamerkan. Lebih baik orang lain yang memberikan penilaian terhadap keberadaan kita daripada kita harus gembar gembor demikian sikap orang Karo pada umumnya terhadap keberadaan dirinya. 
8. Bunga Rincole merupakan salah satu jenis bunga yang ada di masyarakat Karo. Bunga ini berwarna putih dan harum aromanya. Digunakan sebagai salah satu penghias rumah adat karo, melambangkan hidup yang bermakna bagi orang lain, memberi "keharumana". Hidup bukan untuk sendiri tapi juga bagi sesama. Dengan memperhatikan dan berbagi bagi sesama. Dalam masyarakat Karo yang hidup dari pertanian, berbagi hasil bumi saat panen sudah menjadi tradisi. Bahkan seseorang dapat memetik hasil kebun orang lain kalau untuk keperluan sendiri dan bukan untuk dijual.Warna putih melambangkan ketulusan. Tulus dalam bertutur, bersikap dan bertindak.

9. Pucuk tenggiang. Merupakan bagian dari pakis. Tepatnya bagian pucuk dari pakis. Di tanah Karo banyak sekali tumbuh pakis. Tanah Karo yang subur menyebabkan tanaman pakis tumbuh di sekitar pekarangan rumah, kebun dan berbagai tempat lainnya. Pakis mudah di temui di berbagai tempat di tanah Karo. Pakis menjadi sayuran yang sering dikonsumsi karena selain mudah ditemui juga diyakini dapat meningkatkan kekebalan tubuh, menjaga kesehatan mata dan menjaga agar kadar gula darah seimbang. Tenggiang ini juga diyakini sebagai obat luka, dan pencegah infeksi

10. Pengeret - eret, bila diperhatikan terinspirasi dari cicak. Dipahami sebagai lambang dari kekuatan untuk menolak bala, terhindar dari ancaman roh jahat. Kemampuan beradaptasi (sebab cicak dapat hidup dimana saja, apakah itu di rumah mewah maupun di rumah yang paling sederhana), Artinya setiap orang siap menjalani roda kehidupan. Adakalanya hidup senang dan adakalanya hidup menderita .Maknanya menjalani hidup dengan syukur sehingga seseorang terhindar dari depresi. Selain itu juga sebagai simbol kesatuan keluarga. Hubungan keluarga jangan sampai renggang karena adanya kesenjangan ekonomi maupun social. Kekerabatan dalam masyarakat Karo sangat Erat. Perbedaan tingkat pendidikan, Ekonomi, jabatan tidak membuat seseorang lupa adat. Sekalipun seseorang memiliki jabatan dan kedudukan yang tinggi dalam 
Serat Rupa Journal of Design, January 2021, Vol.5, No.1: 122-141

E-ISSN: 2477-586X, ISSN: 2338-3348 | https://doi.org/10.28932/srjd.v5i1.2868 |

Received: 30- 10- 2019, Accepted: 16- 01- 2021

Seriwati Ginting, Heddy Heriyadi, Sri Bina Carolina

Upaya Pelestarian Rumah Adat Karo Melalui Rupa Ragam Hias di Sumatra Utara

masyarakat namun secara adat tetaplah adat. Misalnya kalau posisinya sebagai anak beru maka dia harus terjun sebagai petugas yang melayani kalimbubu (sekalipun kalimbubu tersebut secara pendidikan, ekonomi dan kedudukan di masyarakat lebih rendah posisinya) dengan ikut memasak, membersihkan peralatan makan dan menghidangkan masakan. Ornamen ini terbuat dari ijuk dan diikatkan ke bagian dinding rumah sebagai pengganti dari paku.

11. Tapak Raja Sulaiman dipercaya dapat menolong masyarakat Karo agar terhindar dari ancaman. Tapak Sulaiman bermotif geometris yang membentuk segi empat dan di setiap sisinya membentuk simpul. Ornamen ini memiliki makna kekeluargaan dan kekuatan.

Ragam hias (ornamen) masyarakat Karo sangat banyak Jenisnya. Ornamen tersebut tidak hanya ditempatkan di rumah adat tetapi juga diaplikasikan pada berbagai benda pakai lainnya seperti sendok, gantang (sejenis alat takar/ukur dimasyarakat Karo), cincin dan sebagainya.. Unsur ragam hias yang diaplikasikan memiliki keterkaitan dengan kepercayaan yang diyakini masyarakat Karo. Ilustrasi rupa visual yang diaplikaksikan pada hiasan rumah adat tradisonal Karo dipengaruhi lingkungan alam sekitar, misalnya pucuk tanaman rambat taruk taruk), susunan daun (Lukisan Umang), susunan bunga serta kuntum bunganya (Bunga Bincole dan Pucuk Tenggiang). Warna yang digunakan juga dipengaruhi warna-warna yang ada dilingkungan alamnya, dimana tumbuhan tumbuh secara subur. Warna yang digunakan diantaranya; hijau, kuning, merah, putih dan hitam. Masyarakat Karo hidup dari beternak, dan bertani dengan menggarap sawah atau kebun. 
Struktur bangunan rumah adat dibuat dengan bentuk persegi panjang, dibagian dalam rumah tidak banyak ruangan. Rumah adat Karo berfungsi sebagai tempat tinggal seperti (berteduh, berlindung, memasak dan makan, bersosialisasi dan istirahat/tidur) namun untuk keperluan mandi, cuci, toilet tidak terdapat di dalam rumah adat Karo. Untuk keperluan mandi, cuci dilakukan di luar rumah, biasanya dilakukan di sungai atau pancuran/toilet umum yang dibuat semi terbuka. Temboknya hanya setinggi rata rata orang dewasa dan tidak ada pintu.

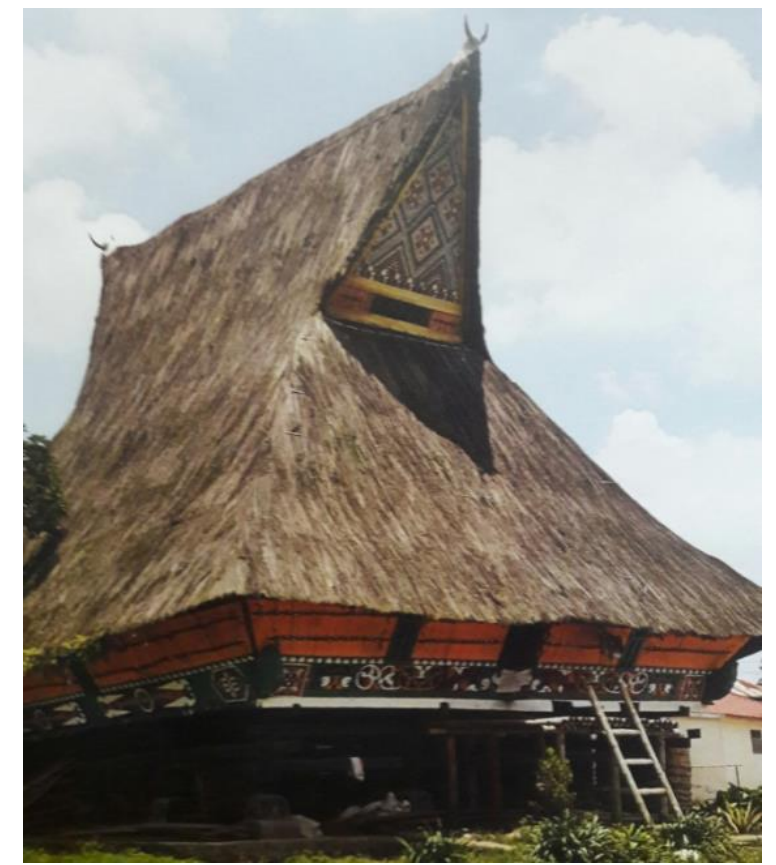

Gambar 11. Rumah Adat Karo Siwaluh Jabu Sumber : Dokumentasi Tim Penulis

Keberadaan rumah adat Karo terus mengalami penurunan. Di desa Lingga menurut informasi yang diperoleh pada wawancara, pata awal tahun 2002 masih terdapat 28 rumah adat Karo, namun saat penelitian ini berlangsung tahun 2015 hanya ada 2 rumah adat di Desa Lingga. usia rumah adat yang ada saat ini telah mencapai 150 tahun, dan pada saat ini hanya dihuni oleh 4 keluarga . Rumah adat Karo merupakan rumah panggung seperti yang tampak pada gamar. Penerapan ragam hias tidak selalu tunggal dalam penempatannya. Adakalanya penempatan ragam hias dipadukan. Penempatan ragam hias tersebut juga tidak selalu sama untuk setiap daerah. Ragam hias pada dinding (derpih) bagian luar dibuat dengan teknik 
Serat Rupa Journal of Design, January 2021, Vol.5, No.1: 122-141

E-ISSN: 2477-586X, ISSN: 2338-3348 | https://doi.org/10.28932/srjd.v5i1.2868 |

Received: 30- 10- 2019, Accepted: 16- 01- 2021

Seriwati Ginting, Heddy Heriyadi, Sri Bina Carolina

Upaya Pelestarian Rumah Adat Karo Melalui Rupa Ragam Hias di Sumatra Utara

ukiran dan penambahan unsur warna. Selain itu pada rumah adat Karo juga dibuat hiasan-hiasan dengan bentuk geometris, seperti, segitiga dan persegi. Ragam hias tersebut tidak semua diberi warna, ada yang tetap dengan warna aslinya seperti kayu dan bambu. Susunan jalinan bambu dtempatkan di bagian atas bangunan (di bawah tanduk kerbau). Tanduk kerbau diyakini oleh masyarakat Karo sebagai lambang kekuatan dan kesuksesan. Dengan menerapkan kepala kerbau pada bagian atap/bubungan maka rumah adat ada yang menjaga/melindungi. Rumah adat yang masih dihuni akan awet, karena adanya asap dari kayu bakar yang digunakan untuk memasak membuat rumah adat akan kuat. Fungsi ragam hias juga berfungsi sebagai identitas strata golongan sosial, penolak bala, dan sebagai hiasan. Hiasan yang dibuat pada bagian atas depan atap dibuat dengan ukiran atau jalinan anyaman bambu, sedangkan pada dinding dibuat bentuk segi tiga, bintang sudut enam dan lebih, sudut segi-empat dan segi empat belah ketupat. Bentuk lengkung geometris seperti bulat dan bulat lonjong tidak tampak dalam hiasan rumahnya. Bentuk-bentuk geometris digunakan pada bagian dinding bagian bawah bangunan dan dibawah ujung atap. Warna yang digunakan dalam bidang hiasan yang berbentuk rupa geometris antara lain, hitam, putih atau kuning. Warna garis yang sering tampil digunakan adalah warna hitam atau putih. Warna putih digunakan terutama kalau bagian latarnya warna gelap.

\section{PENUTUP}

Temuan dalam penelitian ini adalah rumah adat Karo semakin punah, dari tahun ke tahun jumlahnya terus menurun, yang masih tersisa kondisinya kurang terawat. Perbaikan yang dilakukan hanya sekedarnya, misalnya menambal atap yang bocor atau mengganti papan kayu lantai yang rusak. Belum ada upaya yang serius untuk merawat agar kondisi rumah adat terjaga dan terpelihara "secara utuh" (bangunanya, ragam hiasanya juga ruang yang ada di dalamnya). Pemerintah perlu memikirkan membentuk komunitas yang "peduli" untuk membuat berbagai program yang mendukung untuk pemeliharaan, perawatan secara berkesinambungan, bentuknya bisa juga dengan membuat film documenter dan 
berbagai kegiatan lain. Ragam hiasnya memiliki nilai nilai sakral, sebagai penolak bala, mendatangkan keselamatan dan juga nilai keindahan. Perlu perhatian dari pemerintah, pemuka adat dan masyarakat Karo untuk bersama melakukan pelestarian terhadap kekayaan budaya. Dinas Pendidikan dapat memasukkan materi rumah adat dalam muatan lokal kurikulum agar kesadaran budaya dan rasa bangga tumbuh sejak dini atau wisata edukasi ke desa yang masih ada rumah adatnya, sehingga kekayaan rumah adat Karo dapat dinikmati oleh para generasi yang akan datang.

\section{DAFTAR PUSTAKA}

Erdansyah Fuad. (2011). Simbol dan Pemaknaan Gerga Pada Rumah Adat Batak Karo di

Sumatra Utara. Jurnal Pengkajian dan Penciptaan Seni, Vol.7 No. 1. 115139, https://doi.org/10.33153/dewaruci.v7i1.981

Jufli Fauzi. (2012)Makna Simbol Pengeretret Rumah Adat Batak Karo.Analisis Semiotik Charles Pierce Mengenai Makna Simbol Pengereteret Rumah Adat Batak Karo di Sumatra Utara.elib.unicom.ac.id

Ginting Leo Jaoosten (2014). Tanah Karo Selayang Pandang, Mengenal Lebih Dekat Budaya Karo. Medan: Bina Media Perintis

Maundyni Syafindra dkk. (2019). Makna Semiotik Atap Rumah Adat Karo Siwaluh

Jabu Jurnal Basataka (JBT), Basa Taka, Universitas Balikpapan, Vol. 2 No. 2 Desember.

Purba, Sribina Carolina. (2015). Karo Budaya dan Tradisi Laporan Tugas Akhir Jurusan

Desain Komunikasi Visual, Universitas Kristen Maranatha Maranatha

Tarigan Sarjani (2018) Lentera Kehidupan Orang Karo Dalam

Berbudaya, Medan: Si BNB Press

Rina Saraswaty, Suprayitno, (2017). Perubahan bangunan Tradisional Karo Dengan Masyarakat

Pendekatan Arsitektur Vernakuler (Studi kasus: Rumah Tinggal

Karo di Desa Doulu, Berastagi, Kabupaten Tanah Karo, Educational Building 
Jurnal Pendidikan Teknik Bangunan dan Sipil, Fakultar Teknik Universitas Negeri Medan, Vol.3 No.2, : https://doi.org/10.24114/eb.v3i2.8257.

Saragi, Daulat. (2018). Pengembangan Tekstil Berbasis Motif dan Nilai Filosofis Ornamen Tradisional Sumatra . Jurnal Panggung, Institut Seni Budaya Indonesia, Vol.28,161-174,No.2, http://dx.doi.org/10.26742/panggung.v28i2.445.g376.

Sinulingga, R., \& Mahagangga, I. (2016). UPAYA KONSERVASI RUMAH ADAT KARO

DALAM MENUNJANG PARIWISATA BUDAYA DI DESA LINGGA KABUPATEN KARO SUMATERA UTARA. JURNAL DESTINASI PARIWISATA, 4(2), 139 - 145. doi:10.24843/JDEPAR.2016.v04.i02.p25

Sitepu Septyani Emlita, Ardoni (2019). Informasi Budaya Suku

Karo Sumatra.Jurnal IImu Informasi Perpustakaan dan Kearsipan, Vol 8, No. 1,413- 420, https://doi.org/10.24036/107314-0934

https://kamuskaro.com/ https://kebudayaan.kemendikbud.go.id/ditwab/rumah.adat.karo/

https://museumgbkpsukamakmur.files.wordpress.com/2013/07/desa-siwaluh.jpg, diakses 28 Januari 2021

repository.usu.ac.id 